\title{
Geloofsvolharding en moreel-etiese agteruitgang in die lig van die kenmotief in 2 Petrus 1:8-11
}

D.G. (Douw) Breed \& G.J.C. Jordaan

Skool vir Bybelwetenskappe en Bybeltale

Potchefstroomse Universiteit vir $\mathrm{CHO}$

POTCHEFSTROOM

E-pos: dbreed/spyda.co.za

E-pos: sbbgjcj@puknet.puk.ac.za

Abstract

Spiritual perseverance within the situation of moral-ethical degeneration as seen in the light of the motif of knowing in 2 Peter 1:8-11

The purpose of this article is to reflect on the significance of the motif of knowing in 2 Peter 1:8-11 for the current South African context. The motif of knowing in 2 Peter 1:8-11 gives special insight into the manner in which Christians in South Africa can be motivated to live according to God's will. Believers must realize that a life style according to God's will will have a positive effect on their knowledge ('́mi $\gamma \nu \omega \sigma \iota s)$ of Jesus Christ, steadfastness in their belief and the certainty of their pretemporal election. On the other hand, somebody who lives according to his sinful desires disregards the meaning of his baptism. In this article an attempt is also made to show that Peter linked a life lived according to God's will to enter into the eternal kingdom.

\section{Inleiding}

\subsection{Petrus 1:8-11 en die moreel-etiese agteruitgang in Suid- Afrika}

In 'n artikel' oor 2 Petrus 1:3-4 is daarop gewys dat groot agteruitgang op moreel-etiese terrein in Suid-Afrika plaasvind. In die artikel is aangedui dat die verkondiging van die geloofswaarhede waarna Petrus 
in 1:3-11 verwys, werklik in hierdie land 'n verskil kan maak ${ }^{2}$. Waar mense hierdie waarhede aanvaar en tot geloof in Jesus Christus kom, sal hulle nie meer magteloos in morele verderf vasgevang wees nie. Dit blyk egter uit die praktyk dat dit nie slegs ongelowiges is wat op moreeletiese terrein oortree nie. Ook gelowiges, mense wat die geloofswaarhede waarna Petrus verwys, aanvaar het en wat Jesus Christus as Verlosser bely, leef sedeloos en maak hulle skuldig aan korrupsie, diefstal, opstand teen gesag en ander sondes op moreel-etiese terrein. Dit is uit 2 Petrus 1:8-11 duidelik dat Petrus in hierdie gedeelte sy lesers, wat self die geloofswaarhede aanvaar het (vgl. 1:12), motiveer om eties korrek te lewe. Hy maak dit in hierdie verse duidelik dat die wyse waarop die gelowige sy lewe inrig, belangrike gevolge vir die gelowige inhou. Die bestudering van Petrus se motivering van sy lesers kan moontlik riglyne bied vir die wyse waarop gelowiges in Suid-Afrika gemotiveer kan word om op geen wyse deel te hê aan die moreel-etiese verval in hierdie land nie, maar om eerder hulle lewe volgens God se wil in te rig.

\subsection{Die kenmotief en 2 Petrus 1:8-11}

Daar is in twee vorige artikels ${ }^{3}$ oor 2 Petrus 1:3-7 daarop gewys dat daar in 2 Petrus 1:3-11 (en in die hele 2 Petrus) 'n motief aangedui kan word, genoem die kenmotief. Met motief word bedoel 'n herhaalde betekenisvolle element; 'n semantiese eenheid wat ongewysig of met kleiner variasies voorkom. Dit het geblyk dat hierdie kenmotief deur die briefskrywer na vore gebring word deur woorde wat met die besit van inligting te doen

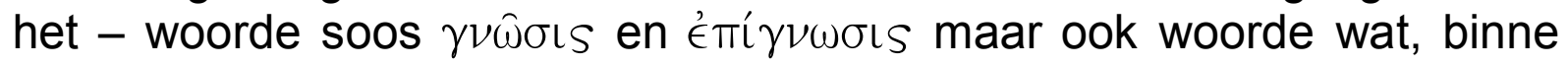
hulle konteks, in betekenisvelde gebruik word wat met die begrip kennis verband hou.

\subsection{Die gedagtekonteks van 2 Petrus 1:8-11}

In 'n artikel oor 2 Petrus 1:3-4 het Breed (2000a:207-229) aangedui dat 2 Petrus 1:3-11 in drie gedagte-eenhede opgedeel kan word:
$1: 3-4$
'n Historiese of teologiese gedeelte
$1: 5-10$ 'n Etiese aanmoedigingsgedeelte
$1: 11$
'n Eskatologiese gedeelte

In 'n opvolgartikel oor 1:5-7 wys Breed (2000b:423-436) daarop dat die etiese aanmoedigingsgedeelte uit twee kleiner gedagte-eenhede bestaan wat vir die doeleindes van die artikel gedagte-eenheid $A$ en gedagte-eenheid $B$ genoem is. Dit het geblyk dat die briefskrywer in

2 Vgl. Breed (2000a:207-229).

3 Vgl. Breed (2000a:207-229). 
gedagte-eenheid $A$ (1:5-7) handel oor die deugde wat die gelowiges by hulle geloof moet voeg, en dat hy in gedagte-eenheid B sy lesers motiveer om eties korrek te lewe.

Terwyl daar in die eerste artikel oor 1 Petrus 1:3-4 gehandel is, het gedagte-eenheid $A$ (1:5-7) van die etiese aanmoedigings gedeelte in die tweede artikel aan die orde gekom. In hierdie derde artikel oor 2 Petrus 1:3-11 word die kenmotief en die betekenis daarvan vir die huidige SuidAfrikaanse konteks in gedagte-eenheid B (1:7-10) en in die eskatologiese gedeelte $(1: 11)$ bestudeer.

\subsection{Opset van die artikel}

Om te bepaal watter riglyne 2 Petrus 1:8-11 bied om gelowiges in SuidAfrika te motiveer om hulle lewe volgens God se wil in te rig, word gedagte-eenheid $B(1: 8-10)$ eerstens bestudeer en tweedens die eskatologiese gedeelte (1:11). Die twee gedeeltes word eksegeties ondersoek en nadat elke gedeelte ondersoek is, word die riglyne wat dit vir die huidige Suid-Afrikaanse konteks bied, aangedui.

\section{Die kenmotief in gedagte-eenheid $B(1: 8-10)$ en die betekenis vir die huidige Suid-Afrikaanse konteks}

Daar word eerstens aandag gegee aan die woorde in gedagte-eenheid $B$ wat die kenmotief dra en daarna word die verband tussen hierdie woorde en gedagte-eenheid $B$ bestudeer. Derdens word die betekenis van die kenmotief in gedagte-eenheid B vir die huidige Suid-Afrikaanse konteks aangedui.

\subsection{Woorde in gedagte-eenheid B wat die kenmotief dra}

Die volgende woorde in gedagte-eenheid $B$ dra moontlik die kenmotief:

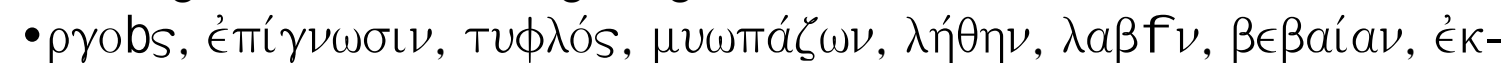
$\lambda \circ \gamma Z u$.

\subsection{1 'Aproùs (1:8)}

Uit Louw en Nida (1988b) is dit duidelik dat die woord ápyós in vyf verskillende semantiese velde gebruik word, te wete: dink (30); optree, doen (42); waarde (65); waar, vals (72); morele en etiese eienskappe en verbandhoudende gedrag (88). Die enigste semantiese veld wat met die besit van inligting verband hou, is die veld dink (30). Binne hierdie veld word ápyós gebruik vir die betekenis van om nie behoorlik aan iets aandag te gee nie. Op 1:8 toegepas, sou dit beteken dat die deugde nie behoorlik aan iets aandag gee nie - 'n betekenis wat binne die konteks 
van 1:8 hoogs onwaarskynlik is. Dit blyk dat Petrus $\ddot{i} \rho$ obo in $1: 8$ nie in betekenisveld 30 aanwend nie, en dit dus nie gebruik om die kenmotief te dra nie. Veel eerder sou aanvaar kon word dat Petrus ï probs in die veld optree, doen (42) aanwend met verwysing na sonder werke. Die woord $і ̈$ probs in 1:8 dra dus nie die kenmotief nie.

\subsection{2 'E}

Soos in 1:34 is 'n goddelike Persoon in 1:8 die objek van '́Ti $\gamma \nu \omega \sigma \iota \nu$. Petrus gee ook geen aanduiding dat hy '́mí $\gamma \nu \omega \sigma \mathrm{s}$ in 1:8 in 'n ander semantiese veld as in 1:1 en 1:3 aanwend nie. Daarom kan aangeneem word dat hy, soos in 1:1 en 1:35, émí $\gamma \nu \omega \sigma \iota \nu$ in die semantiese veld kennis (28) gebruik. Die kenmotief kom dus, soos in 1:1 en 1:3 deur die gebruik van die woord $\epsilon$ ér $\gamma \nu \omega \sigma \iota \nu$ in 1:8 na vore. Daar kan aanvaar word dat Petrus ook, soos in 1:1 en 1:36, $\epsilon$ ér $\gamma \nu \omega \sigma \iota s$ in 1:8 gebruik om 'n diepgaande kennis wat in 'n persoonlike verhouding tot uiting kom, aan te dui.

\subsubsection{Tuф入ós (1:9)}

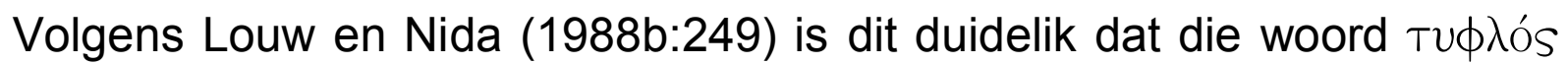
in twee semantiese velde aangewend word, te wete die semantiese velde fisiologiese prosesse en toestande (24) en verstaan (32). Petrus impliseer beslis nie in 1:9 die fisiologiese toestand van die persone na wie hy verwys nie, maar hulle vermoë om te verstaan. Daar kan dus

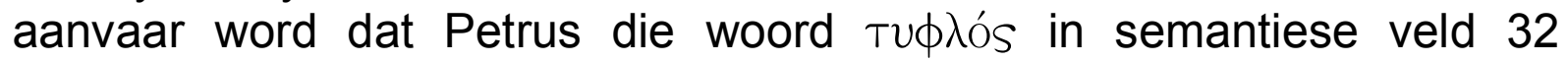
aanwend en die kenmotief deur die gebruik van dié woord laat figureer.

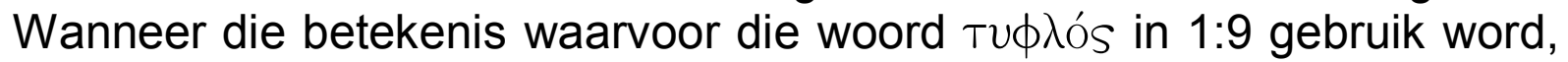
volgens die metode van komponensiële analise nagegaan word, blyk dit dat $\tau \cup \phi \lambda$ ós verband hou met die evaluering van inligting en dié woord die klem laat val op die totale onvermoë om te verstaan.

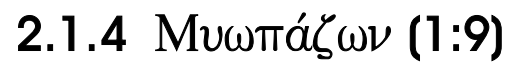

Volgens Louw en Nida (1988b:166) word $\mu v \omega \pi a ́ \zeta \omega$ slegs in een semantiese veld, naamlik die semantiese veld verstaan (31) gebruik. Die woord $\mu \nu \omega \pi \alpha ́ \zeta \omega \nu$ in 1:9 dra dus die kenmotief. Wanneer die betekenis waarvoor die woord $\mu v \omega \pi \alpha ́ \zeta \omega \nu$ in 1:9 gebruik word volgens die metode van komponensiële analise nagegaan word, blyk dit dat dit dui op 'n

\footnotetext{
4 Vgl. Breed (2000a:207-229).

5 Vgl. Breed (2000a:207-229).

6 Vgl. Breed (2000a:207-229).
} 
uitsonderlike gebrek aan vermoë om inligting te gebruik om tot die korrekte begrip of evaluering te kom.

\subsection{5 $\Lambda \eta ́ \theta \eta \nu ~ \lambda \alpha \beta \omega ́ v \quad(1: 9)$}

Petrus gebruik $\lambda \alpha \beta \omega ́ v$ in 1:9 in 'n perifrastiese konstruksie saam met $\lambda \hat{\theta} \theta \eta \nu$. Daar kan aanvaar word dat $\lambda \alpha \beta \omega \dot{\omega} \nu$ in hierdie konstruksie in semantiese veld 18 aangewend vir die betekenis om iets sonder geweld te neem (vgl. Louw \& Nida, 1988a:220). Petrus wil deur die woord $\lambda \alpha \beta \omega \omega_{\nu}$ duidelik maak dat die persone wat in 1:9 ter sprake is, $\lambda \eta \dot{\theta} \eta \nu$ geneem het $(\lambda \alpha \beta \omega \nu)$. Die woord $\lambda \hat{\theta} \theta \eta$ (1:9) word alleenlik in die semantiese veld geheue en herinner (29) gebruik (vgl. Louw \& Nida, 1988b:152). $\Lambda \eta ́ \theta \eta v$ bring dus in 1:9 die kenmotief na vore. Louw en Nida (1988a:348) toon aan dat die woord $\lambda \eta \hat{\theta} \eta$ slegs in een subdomein, te wete die subdomein om nie te onthou nie, vergeet (C) gebruik word. In hierdie subdomein word $\lambda \eta \dot{\theta} \theta \eta$ aangewend vir die betekenis om nie inligting op te roep nie en daarom die betekenis daarvan uit die oog te verloor. Op grond van die metode van komponensiële analise van die woord $\lambda \eta \dot{\theta} \eta$ afgelei kan word dat die woord in 1:9 verband hou met die onvermoë om inligting uit die geheue te herroep. In aansluiting by hierdie aspek word die klem geplaas op die gevolge wanneer die inligting nie herroep word nie, te wete dat die betekenis daarvan uit die oog verloor word. Die betekenis waarvoor die woord gebruik word, kan in Afrikaans met "uit die oog verloor" of "vergeet" aangedui word.

Deur die perifrastiese konstruksie $\lambda \eta \dot{\theta \eta \nu} \lambda \alpha \beta \hat{\omega} \nu$ in 1:9 word dus beklemtoon dat inligting asook die gevolge daarvan, nie uit die geheue opgeroep word nie wanneer hierdie inligting uit die oog verloor word.

\subsubsection{Beßaíav (1:10)}

Volgens Louw en Nida (1988b:45) word Béßaı́s in drie semantiese velde aangewend te wete binne die velde ken (28); 'n perspektief hê, glo, vertrou (31) en wyse (71). Van Houweling (1993:40) toon oortuigend aan dat Petrus $\beta \in \beta a ́ l \alpha \nu$ gebruik om aan te dui dat die lesers hulle geloof moet bevestig. Hy wys daarop dat "heel het christelijk leven is de vrug van Gods inisiatief om geloof te schenken (zie 1:1,5)". Daaruit blyk dit die beste te wees om aan te neem dat Petrus $\beta \in \beta a ́ l \alpha \nu$ in 1:10 in semantiese veld 28 gebruik. Dit beteken dat die kenmotief ook deur die woord $\beta \in \beta a ́ l \alpha \nu$ in 1:10 gedra word. Louw en Nida (1988a:340) toon aan dat $\beta \epsilon ́ \beta$ alos slegs in een subdomein in semantiese veld 28 aangewend word, te wete in die subdomein goed bekend, duidelik aangedui, geopenbaar (C). Wanneer die woord in hierdie subdomein aangewend word, verwys dit na dit wat met sekerheid geweet word (Louw \& Nida, 1988a:340). Op grond van die metode van komponensiële analise van 
die woord $\beta \epsilon ́ \beta$ aıos blyk dit dat die woord in 1:9 veronderstel dat inligting reeds verkry is. Die woord verwys na dit wat met sekerheid bekend is; dit wat geverifieer is.

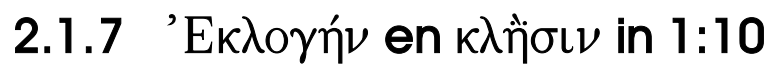

Van Houwelingen (1993:39-40) en Hiebert (1989:59) wys daarop dat $\epsilon \kappa \lambda \circ \gamma \eta \dot{v} \nu$ en $\kappa \lambda \hat{\eta} \sigma \iota \nu$ in 1:10 'n grammatikale eenheid vorm. Hoewel slegs

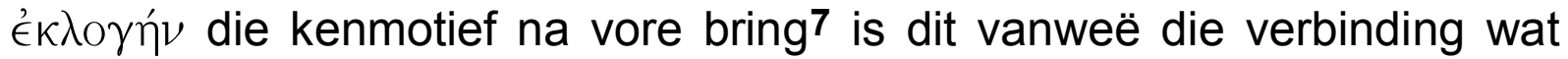
die twee woorde in 1:10 met mekaar het, belangrik dat aandag gegee sal word aan betekenisse waarvoor albei hierdie woorde gebruik word.

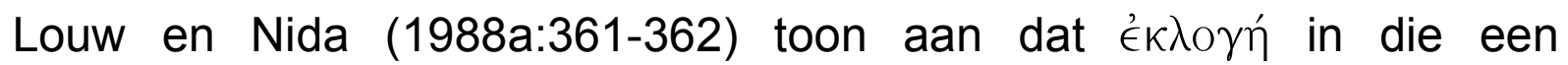
semantiese veld waarin dit aangewend word (semantiese veld 30), in slegs een subdomein gebruik word, naamlik die subdomein om te kies, om uit te soek, om voorkeur te hê vir $(\mathrm{F})$. In subdomein $\mathrm{F}$ word die woord vir die volgende twee betekenisse aangewend:

- Om 'n besondere keuse te maak wat op betekenisvolle voorkeur berus en wat dikwels 'n sterk toegeneë houding teenoor die persoon of iets wat gekies word, impliseer (30.92).

- Dit wat gekies is (30.93).

Dit is uit die konteks duidelik dat Petrus in 1:10 nie handel oor iets of iemand wat 'n keuse moet maak nie, maar oor 'n keuse wat gemaak is.

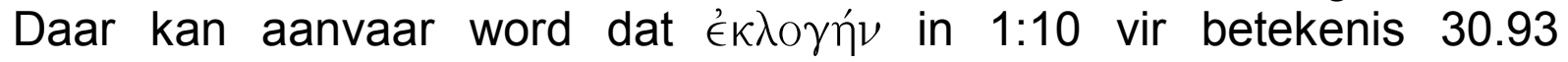
aangewend word. Die semantiese veld dink (30) is nou verbind met die semantiese veld ken (28) en kan as opvolgend op semantiese veld 28 beskou word. Terwyl veld 28 oor die besit van inligting handel, behels veld 30 die beheer en verwerking van inligting - 'n handeling wat dikwels

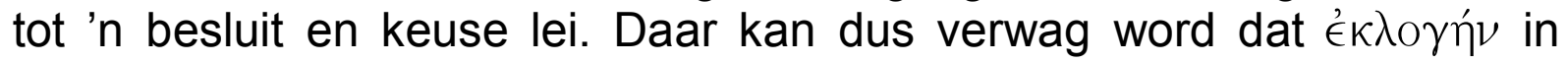
$1: 10$, wat in veld 30 aangewend word, die besit van inligting behels. Wanneer die betekenis waarvoor '́k $\lambda \circ \gamma \eta \dot{v} v$ volgens die metode van komponensiële analise gedefinieer word, blyk dit dat die woord in 1:10

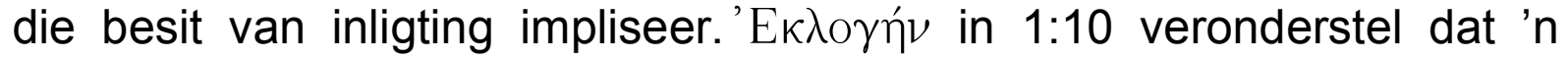

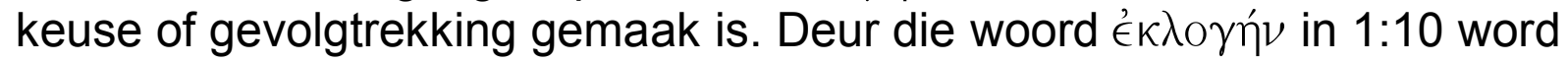
beklemtoon dat die persoon wat die keuse gemaak het, 'n besondere voorkeur het vir die persoon of objek wat gekies word, en dat hierdie voorkeur moontlik 'n gunstige houding impliseer. Hierdie voorkeur en houding is egter nie gefundeer op enige eienskappe wat die voorwerp of persoon wat gekies word, mag besit nie. Wanneer die konteks

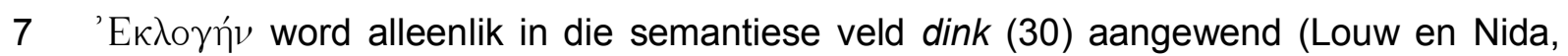
1988b:78). Hierdie semantiese veld is aan die kenmotief verbind, en die kenmotief

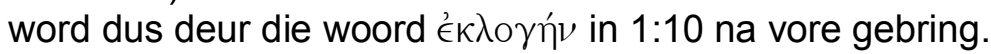




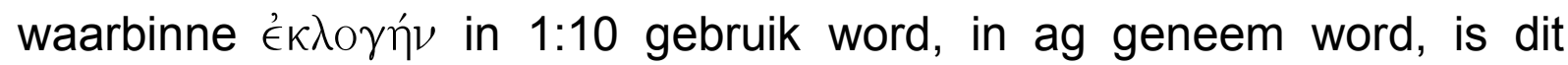
duidelik dat die persoon wie se keuse ter sprake is, God is. In die lig daarvan dat God se verkiesing ter sprake is, kan aangeneem word dat

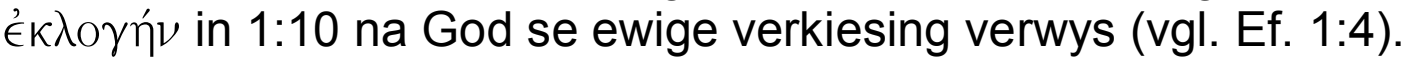

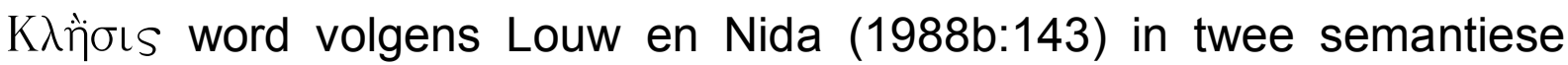
velde gebruik, naamlik kommunikasie (33) en status (87). Wanneer $\kappa \lambda \ddot{j} \sigma \mathrm{s}$ in semantiese veld kommunikasie in die subdomein roep (C) aangewend word, bring die woord volgens Louw en Nida (1988a:424) twee aspekte na vore, te wete die verantwoordelikheid van die persoon wat geroep word, asook die verhouding van die persoon wat geroep word, het met die persoon wat roep. In die konteks waarin $\kappa \lambda \hat{j} \sigma \mathrm{s}$ gebruik word, beklemtoon Petrus sowel die lesers se verantwoordlikheid as die verhouding waarin hulle staan. In 1:5-7 wys hy die lesers op hulle verantwoordelikheid om hulle lewens volgens sekere vereistes in te rig en in 1:2 en 1:8 beklemtoon hy hulle verhouding met God en Jesus Christus. Daar kan dus aanvaar word dat Petrus die woord $\kappa \lambda \hat{\eta} \sigma \iota s$ in die semantiese veld kommunikasie in die subdomein roep (C) aanwend. Binne subdomein roep word die woord vir twee betekenisse gebruik, naamlik die betekenisse om iemand dringend op te roep om verantwoordelikheid vir 'n spesifieke taak te aanvaar terwyl 'n nuwe verhouding met die een wat roep, veronderstel word (33.312) en om geroep te wees vir 'n spesifieke taak en/of verhouding (33.313). Dit is uit die aanhef (1:2) duidelik dat die lesers reeds gelowiges is, aangesien Petrus sê dat hulle reeds geloof ontvang het. Die lesers word nie opgeroep om te glo nie. Hulle is deur God geroep en het in geloof geantwoord op die roeping en het nou as geroepenes ' $n$ spesifieke verantwoordelikheid. Dit blyk dus dat Petrus $\kappa \lambda \hat{\eta} \sigma \mathrm{s}$ s vir betekenis 33.313 gebruik. Wanneer $\kappa \lambda \hat{j} \sigma \iota s$ volgens die metode van komponensiële analise bestudeer word, staan die twee betekeniskomponente wat reeds gemeld is, op die voorgrond. Met dié woord beklemtoon Petrus dat die lesers in 'n spesifieke verhouding staan en 'n spesifieke verantwoordlikheid het. Die lesers staan as gelowiges in 'n verhouding met God (vgl. 1:2) en Jesus Christus (vgl. 1:2 en 1:8) en het 'n verantwoordelikheid om hulle lewe op 'n spesifieke wyse in te rig (vgl. 1:5-7).

Die vraag ontstaan waarom Petrus roeping eerste noem terwyl verkiesing logies eerste kom (vgl. Rom. 8:30). Hierop antwoord Hiebert (1989:59) oortuigend "... only after we respond to His call can we begin to understand His pretemporal election (Eph. 1:4). Our election becomes a certainty to us only after we have experienced His transforming call (cf. 2 Thess. 2:13-14)". 


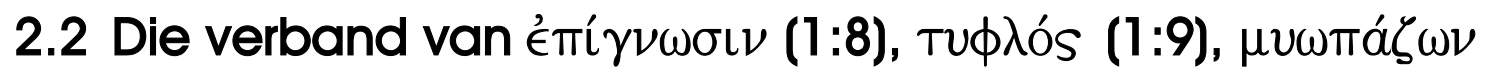

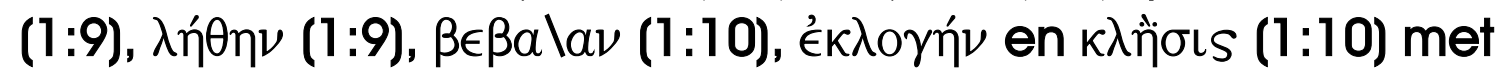
gedagte-eenheid B

Dit is duidelik dat Petrus met die woord tav̂ta in 1:8 verwys na die deugde wat in 1:5-7 vermeld is, en dit blyk dat hy 'n verband lê tussen die deugde en die diepgaande kennis ( $\left.\epsilon^{\prime} \pi \hat{\gamma} \gamma \nu \omega \sigma \iota s\right)$ wat in 1:8 ter sprake gebring word. Hierdie verband word eerstens bestudeer. Daarna word

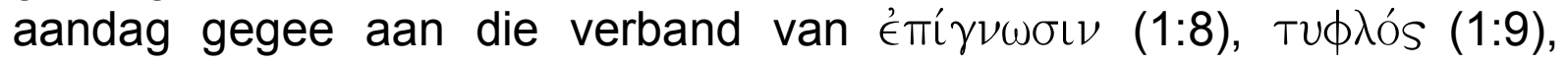

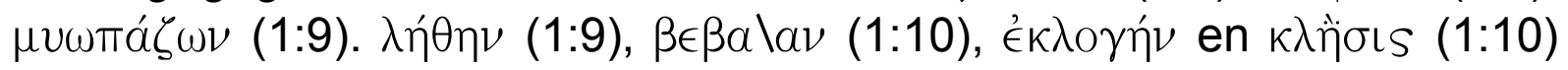
met gedagte-eenheid $B$.

\subsection{1 'E}

Kommentatore verskil of Petrus met die frase $\epsilon i s$ Tìv Tov̂ kupíov $\dot{\eta} \mu \omega \hat{\omega} \nu$ 'I verwys. Bauckham (1983:188-189), Bigg (1969:259), Mounce (1982: 110) en Picirilli (1963:81-82) is oortuig dat Petrus є́mí $\gamma \nu \omega \sigma \iota \nu$ stel as die bron waaruit die deugde voortkom. Om hierdie interpretasie te handhaaf, moet die voorsetsel $\epsilon i s$ vertaal word as "ten opsigte van". Daarteenoor stel Schelkle (1988:191), Schwanck et al. (1978:141), Grundmann (1974: 74) Hiebert (1989:56) en Van Houwelingen (1993:38) dat Petrus $\epsilon \in \operatorname{\epsilon } \gamma \nu \omega \sigma \iota \nu$ die doel of die produk maak van die deugde. Die voorsetsel $\epsilon \triangle$ wys, volgens hierdie interpretasie, rigting aan. Hoewel albei interpretasies moontlik is, blyk dit beter te wees om laasgenoemde te aanvaar. Soos Van Houwelingen (1988:116) tereg opmerk: "Na de twee predikatief gebruikte adjektieven werkeloos en vruchteloos moet de konstruksie $\epsilon i s . . . \epsilon^{\prime} \pi i \gamma \nu \omega \sigma \nu \nu$ wel een bepaalde richting aangeven". Petrus stel die diepgaande kennis in 1:8-9 dus as doel van die deugde wat in 1:5-7 vermeld word.

Deur middel van litotes maak Petrus dit duidelik wat die doel van die deugde is. Hy ontken dat die deugde die lesers sonder werke ${ }^{8}$ en sonder vrugte 9 met betrekking tot die kennis van Jesus Christus sal laat. Deur hierdie litotes beklemtoon Petrus dat die resultate van die deugde verseker is. Die deugde sál die lesers ywerig maak met betrekking tot die kennis van Jesus Christus en sál vir die lesers vrugte dra met betrekking tot die kennis van Jesus Christus.

8 Die woord ảproùs in 1:8 verwys na werkeloos (vgl. Louw \& Nida, 1988a:515).

9 Die woord ákáptous verwys in 1:8 na die betekenis om nie saad, vrugte of 'n oes te produseer nie (vgl. Louw \& Nida, 1988a:276). 
Dit blyk uit bogaande dat die deugde 'n tweeledige resultaat verseker. Enersyds verseker dit die lesers van ywer: die lesers sal ywerig die diepgaande kennis van Jesus Christus najaag. Andersyds verseker die deugde die lesers daarvan dat hulle die vrugte van die diepgaande kennis sal ontvang: hulle sal die diepgaande kennis belewe.

Petrus stel egter deur middel van twee deelwoorde twee voorwaardes om bogenoemde doelstelling te bereik. Dit blyk dat Petrus die twee

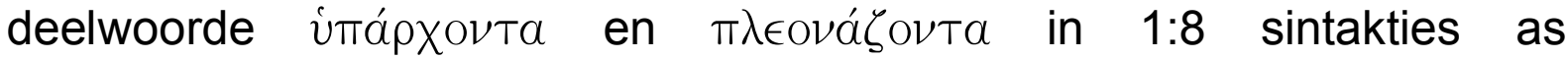
voorwaardelike bepaling gebruik. Die deugde sal die lesers ywerig maak

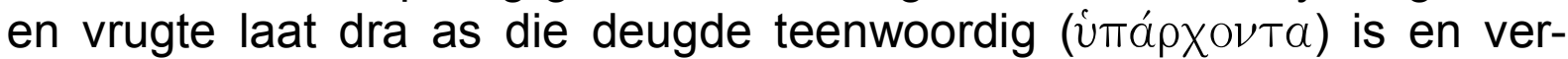

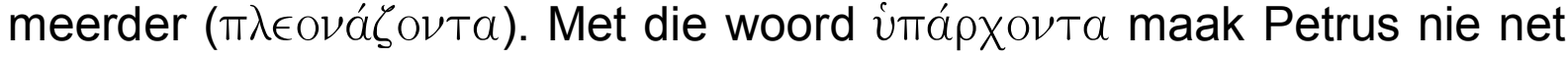
duidelik dat die deugde aanwesig moet wees nie, maar druk hy die lesers dit op die hart dat hulle die deugde hulle eie moet maak ${ }^{10}$. Deur

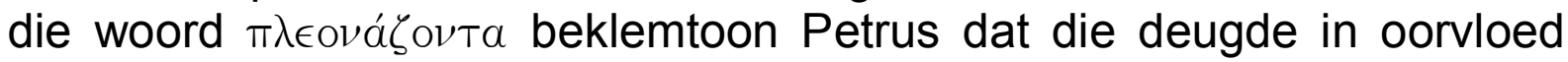
teenwoordig moet wees ${ }^{11}$. Dit blyk dus dat Petrus die lesers motiveer om die deugde wat in 1:5-7 vermeld is, by te voeg deur die diepgaande kennis van Jesus Christus as doelstelling voor te hou. Hy maak dit vir hulle duidelik dat, wanneer die deugde deel word van iemand se lewe en dit toeneem, daardie selfde deugde tweërlei gevolge vir iemand inhou: enersyds maak dit hom ywerig om die kennis na te jaag; andersyds sal dit hom die kennis van Jesus Christus laat ervaar as 'n diepgaande kennis wat in 'n persoonlike verhouding met Christus tot uiting kom.

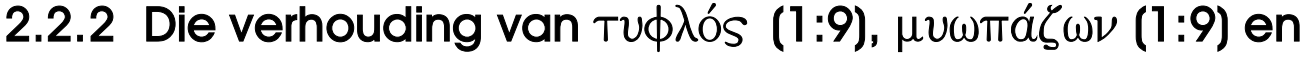 $\lambda \eta ́ \theta \eta \nu \lambda \alpha \beta \omega ́ v(1: 9)$ tot die motivering om eties korrek te lewe}

Petrus maak in 1:9 duidelik in watter toestand iemand verkeer wat nie die deugde besit (vgl. Tav̂Ta, 1:9) waarna hy in 1:5-7 verwys nie. Hierdie toestand staan in kontras met die toestand wat hy in 1:8 geskets het.

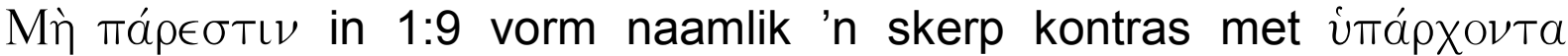

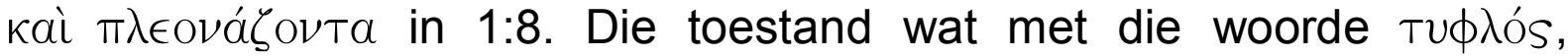
$\mu v \omega \pi \alpha ́ \zeta \omega \nu$ en $\lambda \eta \dot{\theta} \eta \nu$ geskets word, vorm ook 'n skerp kontras met die doelstelling van die deugde wat in 1:8 geskets word (vgl. punt 2.2.1).

Petrus bestempel iemand by wie die deugde nie teenwoordig is nie,

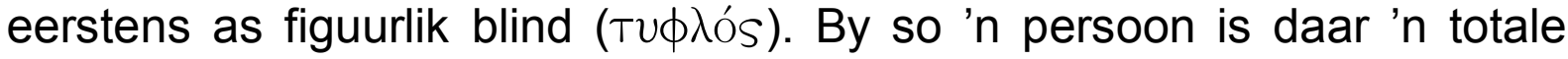
onvermoë om te verstaan (vgl. punt 2.1.3 vir die betekenis waarvoor die woord TU $\phi \lambda$ ós gebruik word). Petrus maak dit egter tweedens ook duidelik dat so iemand figuurlik kortsigtig $(\mu v \omega \pi \alpha ́ \zeta \omega \nu)$ is. Die persoon het dus

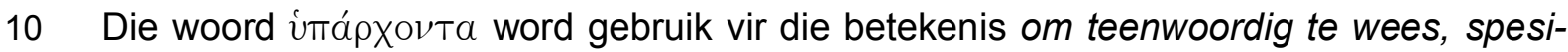
fiek in verband met eienaarskap (vgl. Louw \& Nida, 1988a:158).

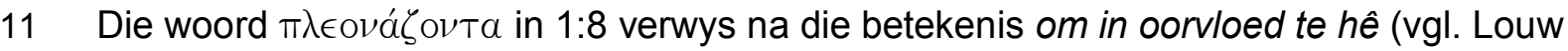
\& Nida, 1988a:599). 
'n ernstige gebrek in sy vermoë om te verstaan (vgl. punt 2.1.4 vir die betekenis waarvoor die woord $\mu v \omega \pi a ́ \zeta \omega \nu$ gebruik word).

Die vraag ontstaan waarom Petrus eers stel dat so 'n persoon blind is en dan as 't ware dit wat gesê is, gedeeltelik kanselleer deur met $\mu \nu \omega \pi \alpha ́ \zeta \omega \nu$

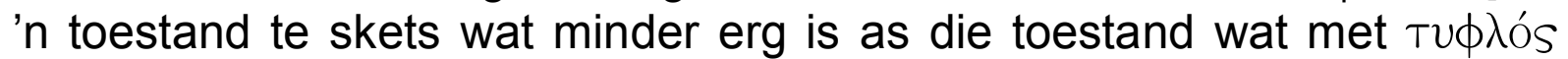
geskets word. Dikwels word aanvaar dat die betekenis waarvoor die woord $\mu v \omega \pi \alpha ́ \zeta \omega \nu$ gebruik word, 'n element van opsetlikheid inhou en dat die skrywer dus die persoon se blindheid op hierdie wyse nader verklaar (Groenewald, 1977:113; Green, 1977:72-73; Kelly, 1969:308; Picirilli, 1963:84). Uit punt 2.1.4 is dit egter duidelik dat die betekeniskomponent opsetlikheid nie figureer in die betekenis waarvoor die woord $\mu \nu \omega \pi \alpha ́ \zeta \omega \nu$ in 1:9 gebruik word nie. Petrus se bedoeling word egter duidelik vanuit die sintaktiese struktuur van 1:9. Die hoofsin in hierdie vers is TU $\phi \lambda$ ós $\epsilon \sigma \tau \iota \nu$. Hierdie hoofsin word bepaal deur twee deelwoordfrases, te wete $\mu \nu \omega \pi \alpha ́ \zeta \omega \nu$ en $\lambda \eta \dot{\theta} \eta \nu \nu \alpha \beta \omega \dot{\nu}$. Die hoofmededeling van die sin is dus dat iemand by wie die deugde nie teenwoordig is nie, ' $n$ totale onvermoë het om te verstaan. Die twee deelwoordfrases dui dan die rede vir die totale onvermoë aan: enersyds is daar by so persoon 'n ernstige onvermoë om inligting aan te wend en tot die regte begrip of evaluering te kom ( $\mu \nu \omega \pi \alpha ́ \zeta \omega \nu)$; andersyds is daar by hom 'n onvermoë omdat hy sekere inligting nie uit die geheue terugroep nie en die betekenis daarvan uit die oog verloor $(\lambda \dot{\eta} \theta \eta \nu \lambda \alpha \beta \omega \dot{\omega} \nu)$.

Uit die konteks van 1:9 kan afgelei word watter inligting so 'n persoon nie korrek kan evalueer of begryp nie. Petrus se lesers is naamlik met twee "stelle inligting" gekonfronteer: aan die een kant die leer van die apostels (1:3-11) en aan die ander kant die leer van die valse leraars. Die apostels het aan hulle geleer dat iemand wat in 'n verbondsverhouding met God te staan gekom het, 'n leefwyse volgens God se wil behoort te voer ${ }^{12}$. Die valse leraars, daarenteen, het 'n leer van "vryheid" verkondig (vgl. 2:19 en Breed, 2000b:423-436), dit wil sê die leer dat die mens vry is om te leef soos hy wil en dat hy nie volgens God se wil hoef te leef nie. lemand by wie die deugde nie voorkom nie, is te kortsigtig om te verstaan watter inligting die korrekte inligting is.

Soos vroeër gestel, bestaan iemand by wie die deugde nie voorkom nie, se totale onvermoë om te verstaan nie net uit kortsigtigheid nie, maar is dit ook geleë in die feit dat vergeet word. Petrus sê uitdruklik watter inligting so 'n persoon vergeet, te wete die reiniging van sy vroeëre

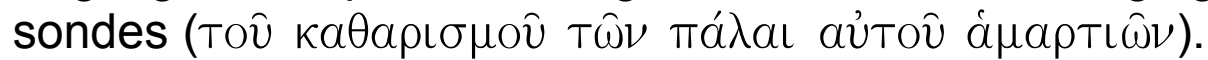

Vgl. Breed (2000a:207-229). 
Skrywers stem in 'n groot mate saam dat Petrus met die woorde to

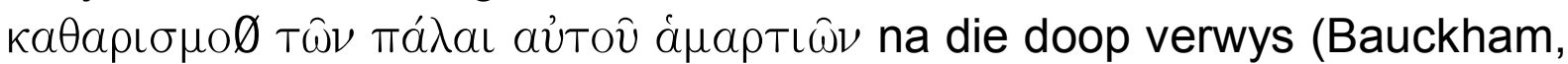
1983:189; Knoch, 1990:242-243; Paulsen, 1992:112; Van Houwelingen, 1993:39). Die ooreenkomste wat hierdie woorde toon met byvoorbeeld Handelinge 22:16, 1 Korintiërs 6:11, Efesiërs 5:26 en Titus 2:14, waar die doop en die reiniging van sondes ook met mekaar in verband gebring word, bevestig hierdie standpunt.

Uit gedeeltes soos 1 Korintiërs 6:11, Handelinge 22:16 en Efesiërs 5:2527 is dit duidelik dat die doop as sodanig nie reiniging bewerk nie, maar dat die heilsgebeure van Jesus Christus se kruisiging en opstanding die groot veronderstelling van die doop is (Floor, 1983:57-60). Petrus leer ook nie in 1:9 dat die doop die reiniging van die sondes bewerk nie. Petrus wil egter duidelik maak dat iemand in wie se lewe die deugde nie voorkom nie, vergeet het wat sy doop aan hom be-teken. Sodanige persoon vergeet dat sy doop aan hom wys dat Christus met sy verlossing 'n radikale breuk bewerk het met die ou lewe - die lewe waarin volgens eie wil geleef is. Hy vergeet ook dat sy doop aan hom leer dat Christus aan hom 'n nuwe lewe gegee het wat volgens God se wil ingerig is.

Dit word duidelik dat Petrus die lesers motiveer tot 'n eties korrekte lewe deur aan hulle te waarsku teen die toestand van iemand in wie se lewe die deugde ontbreek. So 'n persoon het volgens 1:9 'n totale onvermoë om te verstaan. Sodanige persoon se totale onvermoë bestaan eerstens daarin dat hy 'n ernstige onvermoë het om te verstaan dat iemand wat in 'n verbondsverhouding met God te staan gekom het, 'n lewe volgens God se wil behoort te lei. Sy volslae onvermoë om te verstaan, bestaan tweedens daarin dat hy vergeet het wat sy doop be-teken. Hy vergeet dat sy doop hom daarop wys dat Jesus Christus se verlossing 'n radikale breuk met die ou lewe bewerk het en aan hom 'n lewe volgens God se wil geskenk het.

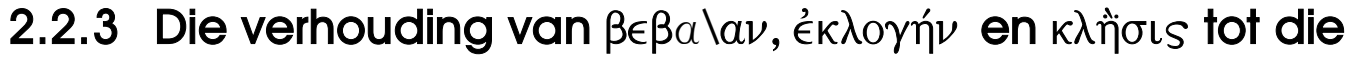 motivering om eties korrek te lewe}

Nadat Petrus in 1:9-10 die lesers tot 'n eties korrekte lewe gemotiveer het, kom hy in 1:10 tot 'n gevolgtrekking13. In hierdie gevolgtrekking moedig Petrus die lesers aan om hulle roeping ( $\kappa \lambda \hat{j} \sigma \iota s)$ en verkiesing

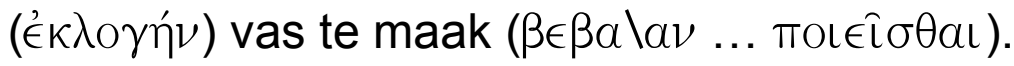

13 Die woord $\delta$ เó in 1:10 gee 'n aanduiding dat 1:10 as gevolgtrekking dien. 
Daar is reeds in punt 2.1.7 aangetoon dat $\beta \in \beta a \mid \alpha \nu$ gebruik word vir die betekenis dit wat met sekerheid bekend is. Daar kan dus met Hiebert (1989:59) saamgestem word dat Petrus nie die lesers oproep om deur hulle eie vermoë hulle roeping en verkiesing sekerder te maak nie. Petrus handel oor die verifiëring van die lesers se roeping en verkiesing. Hulle moet hulle daarvoor beywer dat hulle roeping en verkiesing met sekerheid bekend is.

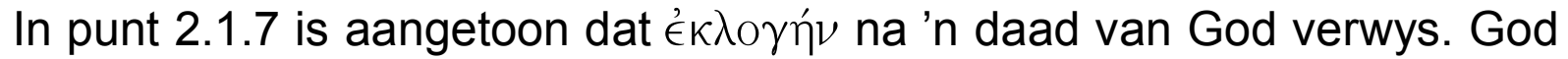
is die Een wat, sonder om enige eienskappe van die persoon wat gekies word in ag te neem, die persoon verkies - 'n keuse slegs omdat Hy 'n besondere voorkeur vir ' $n$ persoon het. In punt 2.1.7 is ook aangetoon dat God die lesers tot 'n verhouding met Hom en tot gehoorsaamheid aan Hom geroep het en dat hulle reeds deur geloof op hierdie roeping geantwoord het. Petrus moedig die lesers in 1:10 aan om te verifieer

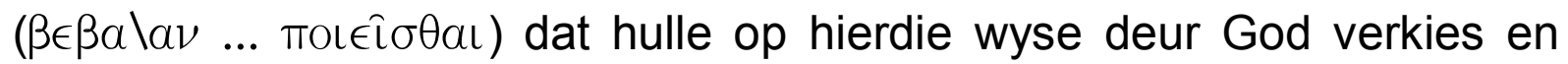
geroep is.

Dit is uit die konteks duidelik hoe die lesers daarin kan slaag om te bevestig dat hulle geroep en verkies is. Die aanmoediging in 1:10 word in 1:8-9 voorafgegaan deur 'n motivering om eties korrek te lewe (vgl. punt 2.2.1 en punt 2.2.2). Op grond van die feit dat hierdie motivering die aanmoediging voorafgaan, blyk dit dat die lesers deur 'n eties korrekte lewe sal verifieer dat hulle deur God verkies is. Indien die deugde wat in 1:5-7 vermeld word, dus deel is van die lesers se lewe en steeds

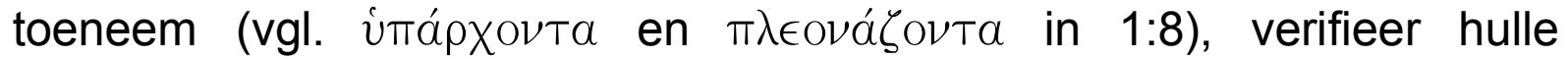
daarmee dat hulle deur God gekies (en geroep ${ }^{14}$ ) is.

Petrus maak in 1:10 seker dat die lesers besef hoe belangrik dit is dat hulle hul roeping en verkiesing verifieer wanneer hy vir hulle aantoon wat die gevolge daarvan is as hulle hul roeping en verkiesing verifieer. Hy sê in 1:10 dat hulle nooit sal struikel as hulle hul roeping en verkiesing bevestig nie. Die skrywer sê daarmee nie dat die lesers nooit weer sal sondig soos Spicq (1966:215-216) en Fornberg (1977:95) beweer nie. Indien Petrus met die woorde "... julle [sal] nooit weer struikel nie" bedoel dat hulle nooit weer sal sondig nie, sou dit neerkom op 'n toutologie. Hy het hulle immers in die aanmoediging om hulle roeping en verkiesing te bevestig in wese ook aangemoedig om nie te sondig nie. Dit sou dus 'n toutologie wees indien hy hulle eers oproep om nie te sondig nie en dan byvoeg: "sodat julle nie sondig nie" (Bauckham, 1983:191). Dit kom eerder voor of Petrus met "nooit struikel nie" bedoel dat diegene wat hulle roeping en verkiesing vasmaak, sonder struikeling sal vorder op die

14 Vir die rede waarom Petrus in 1:11 roeping voor verkiesing plaas, terwyl verkiesing kronologies voor roeping plaasgevind het (Rom. 8:30), vgl. punt 2.1.7. 
pad na die ewige koninkryk: daar is niks wat hulle sal verhinder om in die koninkryk in te gaan nie $(1: 11)$.

Dit is uit die voorgaande duidelik dat Petrus die lesers in 1:10 verder motiveer tot 'n eties korrekte lewe. Hy doen dit deur op grond van dit wat hy in 1:8-9 oor 'n eties korrekte lewe gestel het, 'n gevolgtrekking te maak. In hierdie gevolgtrekking maak hy dit vir die lesers duidelik dat iemand wie se lewe die deugde vertoon wat in 1:5-7 vermeld word, en in wie se lewe die deugde toeneem, daardeur bevestig dat God hom verkies het. Petrus motiveer die lesers verder tot 'n eties korrekte lewe deur hulle op die gevolg te wys wanneer hulle hul roeping en verkiesing bevestig. Hy laat hulle verstaan dat hulle dan nooit sodanig sal struikel dat hulle nie die ewige koninkryk van Jesus Christus sal beërwe nie.

\subsection{Die betekenis van die kenmotief in gedagte-eenheid B vir die huidige Suid-Afrikaanse konteks}

- Dit is uit 2 Petrus 1:8-11 duidelik dat daar nie aanvaar moet word dat gelowiges wat al gevorder het op die pad van heiligmaking vanselfsprekend gemotiveerd sal wees om eties korrek te lewe nie. Petrus motiveer in 1:7-10 op ' $n$ indringende wyse mense wat reeds die aanvaarde geloofswaarhede (TíGTls) besit (vgl. Breed, 2000b:423436), wat reeds in 'n persoonlike verhouding met Jesus Christus staan (vgl. Breed, 2000a:207-229) en wat begin het om die morele verderf in hierdie wêreld te ontsnap (vgl. Breed, 2000a:207-229). In Suid-Afrika is dit dus belangrik dat nie slegs aan ongelowiges ${ }^{15}$ aandag gegee word om die moreel-etiese verval in die land te stuit nie. Ook gelowiges in hierdie land moet voortdurend gemotiveer om nie deel te hê aan, byvoorbeeld korrupsie, geweld, sedeloosheid en opstand teen gesag nie. Gelowiges moet gemotiveer om hulle lewe op moreel-etiese terrein volgens God se wil in te rig.

Uit 2 Petrus 1:8-10 kan 'n aantal riglyne afgelei word waarvolgens gelowiges indringend gemotiveer kan word.

Gelowiges moet onder die besef gebring word dat daar vir hulle tweërlei positiewe gevolge sal wees as hulle hul lewe volgens God se wil inrig. Enersyds sal hulle al hoe meer die begeerte hê om in 'n verhouding met Jesus Christus te staan. Andersyds sal hulle groei in die belewing van hulle persoonlike verhouding met Jesus Christus (vgl. punt 2.2.1). Gelowiges moet egter ook begryp dat hulle hierdie positiewe gevolge slegs sal ervaar as hulle werklik erns maak met 'n lewe volgens God se wil. Die deugde wat by 'n lewe volgens God se 
wil pas, moet nie slegs by hulle teenwoordig wees nie. Hulle moet die deugde hulle eie maak en dit moet toeneem in hulle lewe (vgl. punt 2.2.1). Dit is uit die hoë vlakke van misdaad, korrupsie, geweld en sedeloosheid in Suid-Afrika duidelik dat baie mense oortuig is dat 'n onetiese en immorele leefwyse vir hulle positiewe gevolge kan inhou. Gelowiges mag ook in die versoeking kom om so te redeneer. Wanneer gelowiges egter toegerus is met dit wat Petrus in 1:8 wil leer aangaande 'n leefwyse volgens God se wil, behoort hulle met oortuiging teen hierdie versoeking weerstand te kan bied.

- Gelowiges moet uitdruklik gewaarsku word teen 'n sondige leefwyse deur duidelik te maak in watter toestand iemand verkeer wat in sonde volhard. lemand wat sy lewe volgens sy eie sondige begeertes inrig, het 'n ernstige onvermoë om sekere dinge te verstaan. Sy onvermoë om te verstaan bestaan eerstens daarin dat hy inligting nie so kan aanwend dat hy tot die regte begrip of evaluering kom nie. Hy is te kortsigtig om te begryp dat iemand wat in 'n verbondsverhouding met God staan, sy lewe volgens God se eis wíl inrig. Sy onvermoë om te verstaan bestaan tweedens daarin dat hy sekere inligting nie uit sy geheue terugroep nie en die betekenis daarvan uit die oog verloor. Hy vergeet dat sy doop aan hom be-teken dat Christus met sy verlossing 'n radikale breuk met die ou lewe bewerk het - dié lewe waarin volgens sy eie wil geleef is. Hy vergeet ook dat sy doop aan hom leer dat Christus aan hom 'n nuwe lewe gegee het wat volgens God se wil ingerig is (vgl. punt 2.2.2).

- Die verband tussen God se roeping en sy genadige uitverkiesing aan die een kant en heiligmaking aan die ander kant, moet aan gelowiges verduidelik word. Kerke moet in die verkondiging van die Woord lidmate onder die indruk bring dat 'n lewe volgens God se wil vir die gelowige as bevestiging dien dat hy deur God geroep en uitverkies is. (vgl. punt 2.2.3).

- Om 'n gelowige te motiveer om heilig te lewe, moet die gelowige daarop gewys word dat iemand wat sy roeping en verkiesing deur 'n heilige lewe bevestig, nooit sodanig sal struikel dat hy nie die ewige koninkryk van Jesus Christus sal beërwe nie (vgl. punt 2.2.3).

\section{Die kenmotief in die eskatologiese gedeelte $(1: 11)$ en die betekenis vir die huidige Suid-Afrikaanse konteks}

Die kenmotief in die eskatologiese gedeelte word eerstens nagegaan en daarna word die betekenis daarvan vir die huidige Suid-Afrikaanse konteks ondersoek. 


\subsection{Die kenmotief in die eskatologiese gedeelte}

Dit is opmerklik dat daar in die eskatologiese gedeelte van die apostel se opsomming van sy leer geen woorde voorkom wat die kenmotief dra nie. Dit beteken egter nie dat die kenmotief nie in hierdie gedeelte figureer nie.

Dit is duidelik dat die woorde oútos yáp in 1:11 na 'n saak verwys wat reeds gestel is. Petrus gee deur die gebruik van die woord $\epsilon$ É-

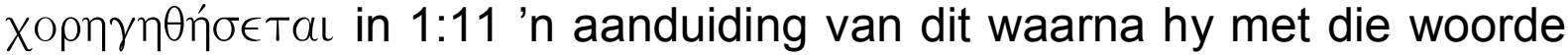

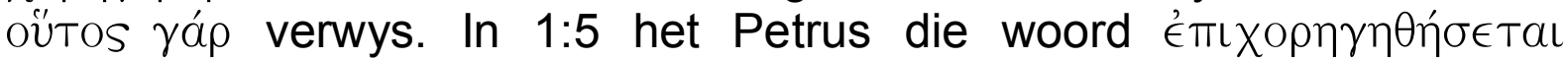
gebruik om vir die lesers duidelik te maak dat hulle nie met die aanvaarde geloofswaarhede wat hulle ontvang het, mag volstaan nie (vgl. Breed, 2000b:423-436). Hulle moet die deugde wat in 1:5-7 genoem

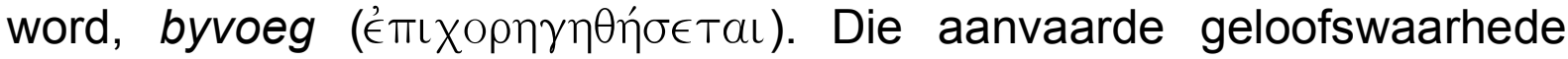
bring die kenmotief na vore (vgl. Breed, 2000a:207-229). Deur die her-

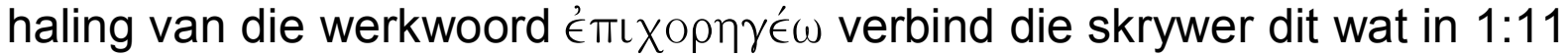
gestel word met die aanmoediging wat hy in 1:5 gegee het (Bigg, 1969:261; Hiebert, 1989:61; Mayor, 1965:98; Picirilli, 1963:93). Hy beklemtoon vir die lesers dat, indien hulle nie volstaan met die aanvaarde geloofswaarhede wat hulle ontvang het nie, maar die deugde byvoeg, God ook vir hulle die toegang in die ewige koninkryk sal byvoeg.

Dit blyk dus dat Petrus, hoewel implisiet, tog in die eskatologiese gedeelte van sy nalatenskap die kenmotief na vore bring. Hy verbind die verantwoordelikheid wat die lesers het met betrekking tot die geloofswaarhede (waarin die kenmotief na vore kom) met die ingaan in die ewige koninkryk. Petrus leer nie dat die lesers deur die byvoeg van die deugde toegang tot die koninkryk verdien nie. Soos Petrus in 1:3-4 beklemtoon het dat daar in genade gegee word (let op $\delta \in \delta \omega \rho \eta \mu \epsilon ́ \nu \eta s$ in

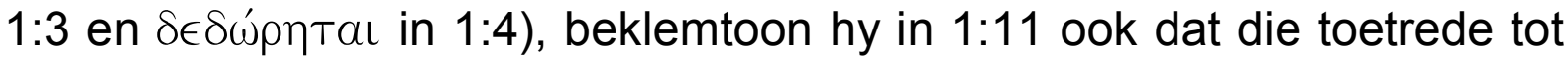
die koninkryk voorsien word. Hy lê ook nadruk daarop dat die ingaan in die koninkryk nie uit verdienste is nie deur dit duidelik te stel dat die koninkryk waartoe die toegang verleen word, die koninkryk van die Verlosser ( $\left.\sigma \omega T \hat{\rho} \rho \rho^{\prime}\right)$ is.

\subsection{Die kenmotief in die eskatologiese gedeelte en die betekenis daarvan vir die huidige Suid-Afrikaanse konteks}

Op grond van die bestudering van die kenmotief in 1:8-10 was dit duidelik dat gelowiges indringend gemotiveer moet word om heilig te lewe. Dit kan nie as vanselfsprekend aanvaar word dat die lewe van gelowiges in Suid-Afrika die deugde sal vertoon wat by 'n Christelike lewe pas nie. Gelowiges moet gemotiveer word om hulle lewe volgens God se wil in te rig (vgl. punt 2.3.1). Die kenmotief in die eskatologiese 
gedeelte laat blyk dat daar aan gelowiges wat hulle lewe volgens God wil inrig, 'n heerlike belofte gegee kan word. Aan die mense wat nie volstaan met die aanvaarde geloofswaarhede wat hulle ontvang het nie, maar wat die deugde wat deel uitmaak van 'n Christelike lewe by die geloofswaarhede byvoeg, voeg God die toegang in die ewige koninkryk by. Hierdie toegang tot die koninkryk word egter nie deur 'n verdienste verkry nie. God gee dit in sy genade.

\section{Bibliografie}

BAUCKHAM, R.J. 1983. Jude, 2 Peter. Texas: Waco. (Word Biblical Commentary, vol. 50.)

BIGG, C. 1969. A critical and exegetical commentary on the epistles of St. Peter and St. Jude. Edenburgh : Clark.

BREED, D.G. 2000a. Verandering van die moreel-etiese situasie in Suid-Afrika, in die lig van die kenmotief in 2 Petrus 1:3-4. In die Skriflig, 34(2):207-229.

BREED, D.G. 2000b. Geloofsverryking te midde van moreel-etiese verwarring, in die lig van die kenmotief in 2 Petrus 1:5-7. In die Skriflig, 34(3):423-436.

FLOOR, L. 1983. Die heilige doop in die Nuwe Testament. Potchefstroom : Potchefstroom Teologiese Publikasies.

FORNBERG, T. 1977. An early church in a pluralistic society: a study of 2 Peter. Lund: Carl Bloms Boktryckeri.

GREEN, M. 1977. The second epistle general of Peter and the general epistle of Jude. An introduction and commentary. Grand Rapids : Eerdmans. (The Tyndale New Testament Commentaries.)

GROENEWALD, E.P. 1977. Die briewe van Petrus. Die brief van Judas. Pretoria : N.G. Kerk-Uitgewers.

GRUNDMANN, W. 1974. Der Brief des Judas und der zweite Brief des Petrus. Berlin : Evangelische Verlagsanstalt. (Theologischer Handkommentar zum Neuen Testament.)

HIEBERT, D.E. 1989. Second Peter and Jude: an expositional commentary. Greenville : Unusual publications.

KELLY, J.N.D. 1969. A commentary on the epistles of Peter and of Jude. London : Adam \& Black.

$\mathrm{KNOCH}, \mathrm{O}$. 1990. Der erste und zweite Petrusbrief. Der Judasbrief. Regensburg : Pustet. (Regensburger Neues Testament.)

LOUW, J.P. \& NIDA, E.A. 1988a. Greek-English lexicon of the New Testament based on semantic domains. (Vol. 1.) New York : United Bible Societies.

LOUW, J.P. \& NIDA, E.A. 1988b. Greek-English lexicon of the New Testament based on semantic domains. (Vol. 2.) New York : United Bible Societies.

MAYOR, J.B. 1965. The epistle of St. Jude and the second epistle of St. Peter. Grand Rapids : Baker Book House.

MOUNCE, R.H. 1982. A living hope. A commentary on 1 and 2 Peter. Grand Rapids : Eerdmans.

PAULSEN, H. 1992. Der zweite Petrusbrief und der Judasbrief. Göttingen : Vandenhoeck \& Ruprecht. (Kritisch-exegetischer Kommentar über das Neue Testament.)

PICIRILLI, R.E. 1963. An exegesis of the Greek text of second Peter, chapters one and two. Greenville : Bob Jones University. (D.Phil. Thesis.)

SCHELKLE, K.H. 1988. Die Petrusbriefe. Der Judasbrief. Freiburg : Herder. (Herders Theologischer Kommentar zum Neuen Testament.) 
SCHWANK, B., STÖGER, A. \& THÜSING, W. 1978. The epistles of St. Peter, St. John and St. Jude. London : Sheed \& Ward.

SPICQ, C. 1966. Les épitres de saint Pierre. Paris : Librairie lecoffre. (Sources Bibliques.)

VAN HOUWELINGEN, P.H.R. 1988. De tweede trompet: de authenticiteit van de tweede brief van Petrus. Kampen : Kok. (Proefschrift - Theologische Universiteit van de Gereformeerde Kerken in Nederland te Kampen.)

VAN HOUWELINGEN, P.H.R. 1993. 2 Petrus en Judas: testament in tweevoud. Kampen : Kok. (Commentaar op het Nieuwe Testament.)

\section{Kernbegrippe:}

geloofsvolharding

kenmotief : 2 Petrus 1:8-11

moreel-etiese agteruitgang

\section{Key concepts:}

moral-ethical degeneration

motif of knowing: 2 Peter 1:8-11

perseverance in faith 